\title{
Variance in employee engagement: A qualitative analysis amongst public school teachers in the Cape Winelands education district
}

\begin{tabular}{|c|c|}
\hline \multicolumn{2}{|c|}{$\begin{array}{l}\text { Authors: } \\
\text { Nicola Vermooten }{ }^{1} \\
\text { Johan Malan } \\
\text { Billy Boonzaier }\end{array}$} \\
\hline \multicolumn{2}{|c|}{$\begin{array}{l}\text { Affiliations: } \\
{ }^{1} \text { Department of Industrial } \\
\text { Psychology, Faculty of } \\
\text { Economic and Management } \\
\text { Sciences, Stellenbosch } \\
\text { University, Cape Town, } \\
\text { South Africa }\end{array}$} \\
\hline \multicolumn{2}{|c|}{$\begin{array}{l}\text { Corresponding author: } \\
\text { Nicola Vermooten, } \\
\text { nicolavanderwest@gmail.com }\end{array}$} \\
\hline \multicolumn{2}{|c|}{$\begin{array}{l}\text { Dates: } \\
\text { Received: } 18 \text { July } 2018 \\
\text { Accepted: } 19 \text { Feb. } 2020 \\
\text { Published: } 28 \text { Apr. } 2020\end{array}$} \\
\hline \multicolumn{2}{|c|}{$\begin{array}{l}\text { How to cite this article: } \\
\text { Vermooten, N., Malan, J., \& } \\
\text { Boonzaier, B. (2020). Variance } \\
\text { in employee engagement: } \\
\text { A qualitative analysis amongst } \\
\text { public school teachers in the } \\
\text { Cape Winelands education } \\
\text { district. SA Journal of } \\
\text { Industrial Psychology/SA } \\
\text { Tydskrif vir Bedryfsielkunde, } \\
46(0), \text { a1568. https://doi.org/ } \\
\text { 10.4102/sajip.v46i0.1568 }\end{array}$} \\
\hline \multicolumn{2}{|c|}{$\begin{array}{l}\text { Copyright: } \\
\text { (C) 2020. The Authors. } \\
\text { Licensee: AOSIS. This } \\
\text { is licensed under the } \\
\text { Creative Commons } \\
\text { Attribution License. }\end{array}$} \\
\hline \multicolumn{2}{|l|}{ Read online: } \\
\hline 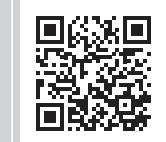 & $\begin{array}{l}\text { Scan this QR } \\
\text { code with your } \\
\text { smart phone or } \\
\text { mobile device } \\
\text { to read online. }\end{array}$ \\
\hline
\end{tabular}

Orientation: The Global Competitiveness Index Report 2017 - 2018, which ranks the quality of 124 countries' education system, positioned South Africa 114th. Challenges with the quality of basic education offered in many public schools across South Africa are attributed to the lack of employee engagement amongst teachers.

Research purpose: The aim of this study was, firstly, to identify the most salient antecedents of variance in employee engagement amongst teachers and, secondly, to explore the relational dynamics that exist amongst these antecedents.

Motivation for the study: The study was motivated by the intention to inform human resource practices and interventions that can be adopted to facilitate optimal teacher engagement and subsequently performance.

Research approach/design and method: A modified version of the interactive qualitative analysis (IQA) methodology was adopted to generate and collect primary qualitative data, but the data analysis was performed in accordance with the prescribed methodology. Initial $(n=37)$ and follow-up $(n=28)$ individual interviews were conducted amongst teachers from 12 mainstream public schools in the Cape Winelands education district.

Main findings: Teacher-level, school-level, community-level and societal-level determinants were identified that explain variance in employee engagement amongst teachers.

Practical/managerial implications: Human resource practices and interventions that may nurture employee engagement amongst teachers are recommended.

Contribution/value-add: This study identified the most salient antecedents of variance in employee engagement amongst teachers in the Cape Winelands District and the findings allow for a number of recommendations regarding interventions to facilitate teacher engagement and ultimately performance.

Keywords: positive psychology; employee engagement; ecological systems theory; job demands-resources theory; public school teachers; interactive qualitative analysis methodology.

\section{Introduction}

The quality of basic education in South Africa is currently under intense scrutiny. The recently published Global Competitiveness Index Report 2017 - 2018, which ranks the quality of 124 countries' education system, positioned South Africa 114th (World Economic Forum [WEF], 2017). Other cross-national assessments conducted between 2002 and 2016, such as the Progress in International Reading Literacy Study and the Trends in International Mathematics and Science Study, have consistently reported similar levels of educational achievement in South Africa (Howie et al., 2016; Reddy et al., 2012, 2016; Spaull, 2013; Trong, 2010). Whilst the complexity associated with the task of improving the functioning of an education system is well documented in education literature, the How the World's Best Performing School Systems Come Out on Top Report, which examined common attributes of excellent education systems by comparing 25 education systems from across the globe, found that teacher quality is the most salient determinant of the efficiency and performance of an education system (McKinsey \& McKinsey, 2007). Scholarly research has also demonstrated that teacher quality is closely correlated with the functioning of an education system (Darling-Hammond, 2015; Jimerson \& Haddock, 2015). In a similar vein, Schleicher (2011, p. 202) claimed that 'The quality of an education system cannot exceed the quality of its teachers'. In line with the above, the researchers claim that teacher quality is one of the primary driving forces behind the efficiency and performance of the South African education 
system. Regrettably, indicators that signal the lack of employee engagement amongst public school teachers in South Africa are well publicised. As an example, in 2012, Angie Motshekga, the Minister of Basic Education, reported that teachers in South Africa have the highest absenteeism rate in the Southern African Development Community. On average, every teacher was absent for 19.7 days in 2012 (Nkosi, 2013). The absenteeism rate reported in 2017 was equally disconcerting (Gqomo, 2019). In addition, teacher late-coming (Carnoy, Chisholm, \& Chilisa, 2012; Govender, 2016), teacher turnover (Higley, 2013; Mampane, 2012) and attrition (Bernstein, 2015; Maphalala \& Mpofu, 2019) are also causes for concern.

\section{Research problem and objectives}

An overview of the documented antecedents of employee engagement, and specifically teacher engagement (Vermooten, 2018), has led the researchers to conclude that it is necessary to develop an in-depth understanding of the dynamics underlying the most salient antecedents of variance in employee engagement amongst public school teachers in the Western Cape, as well as the interplay between these antecedents in the nomological network, to be able to launch effective interventions aimed at affecting the level of engagement, and in doing so improving the efficiency and performance of the education system.

The primary objective of the study was, therefore, to develop a conceptual model of the most salient antecedents of variance in employee engagement. More specifically, the study aimed to

- identify the most salient antecedents of variance in employee engagement amongst public school teachers in the Western Cape

- explore the relational dynamics that exist amongst the most salient antecedents of variance in employee engagement amongst these teachers

- recommend human resource practices and interventions to nurture employee engagement amongst the teachers.

\section{Literature review Employee engagement}

Research regarding the engagement phenomena continues to be plagued by two issues. Firstly, there are several definitions of employee engagement. Even though employee engagement is a widely researched construct, researchers do not agree on what this 'slippery' construct means (Schaufeli \& Salanova, 2011, p. 1). Secondly, there is not a generally accepted theory of employee engagement. A number of theories have been developed to explain the engagement phenomenon. Wollard and Shuck (2011) identify four different approaches, namely, the needs satisfying approach, which refers to an expression of the self in work roles; the burnout antithesis approach, which refers to engagement being the opposite of burnout; the satisfaction-engagement approach, which refers to engagement as a form of job satisfaction; and the multidimensional approach, which clearly distinguishes between job and organisational engagement. It is, therefore, necessary to clarify how employee engagement will be defined in the study and which theory will be used to frame the phenomenon.

\section{The meaning of employee engagement}

The most influential definitions of employee engagement that are mentioned throughout engagement literature were introduced by Kahn (1990), Maslach and Leiter (1997) and Schaufeli, Salanova, Bakker, and González-Romá (2002). The researchers decided to conceptualise employee engagement in accordance with Schaufeli et al. (2002) in the study. Schaufeli et al. (2002, p. 74) defined employee engagement as 'a positive, fulfilling, work-related state of mind that is characterised by vigour, dedication, and absorption'.

Vigour denotes a positive affective response to work, characterised by feelings of cognitive liveliness, emotional energy and physical strength. Dedication refers to being actively involved with work. Absorption denotes a complete captivation with work. This dimension of employee engagement approximates Csikszentmihalyi's (1997) conceptualisation of flow, whereby employees experience an optimal state of focused attention and intrinsic enjoyment in their work. Absorbed employees are fully immersed in their work.

Two considerations informed the researchers' decision to conceptualise employee engagement in accordance with Schaufeli et al. (2002). Firstly, this conceptualisation recognises employee engagement and job burnout as two independent but correlated mental states, as opposed to mutually exclusive mental states (Maslach \& Leiter, 1997). This acknowledges that employees, who are not engaged in their work, are not necessarily burnt out, but disengaged from their work. Secondly, Schaufeli et al.'s (2002) conceptualisation accounts for the affective (i.e. vigour), motivational (i.e. dedication) and cognitive (i.e. absorption) aspects of employee engagement. This acknowledges that employee engagement involves emotion, motivation and cognition. The researchers are of the opinion that the abovementioned considerations recognise the complexity of the engagement phenomena.

\section{Theories of employee engagement}

Theories of employee engagement primarily originate from two areas of research, namely, personal engagement and personal disengagement (Kahn, 1990), and employee wellbeing and job burnout (Maslach \& Leiter, 1997). The researchers decided to use the job demands-resources (JD-R) theory (Demerouti, Bakker, Nachreiner, \& Schaufeli, 2001) as a metatheoretical framework in the study to lay the theoretical foundation of the study. The JD-R theory originated from burnout literature. It was in fact initially referred to as the JD-R model of burnout.

The JD-R model of burnout proposed that job burnout is a function of two broad categories of work conditions, namely, 
job demands and job resources. Demerouti et al. (2001) explained that job demands are 'physical, social, or organisational aspects of the job that require sustained physical or mental effort and are, therefore, associated with certain physiological and psychological costs'. In accordance with Hockey's (1997) model of compensatory control, the JD-R model suggested that employees require additional energy to deal with job demands. It is, however, important to mention that job demands may present either a challenge (i.e. challenging job demands) or a hindrance (i.e. hindering job demands) to employees. This is consistent with the LePine, Podsakoff and LePine (2005) distinction between hindrance stressors and challenge stressors.

Hindering job demands, such as role ambiguity or bureaucracy, are excessive or undesirable constraints that hinder employees' ability to achieve work goals (Cavanaugh, Boswell, Roehling, \& Boudreau, 2000). In contrast, challenging job demands, such as complex work tasks or time pressure, require sustained physical, mental and/or psychological effort and skills, but promote employees' personal growth and achievement (Podsakoff, LePine, \& LePine, 2007). It is, therefore, to be expected that challenging job demands are typically appraised as rewarding work experiences - worth the effort and skills that they require (Bakker \& Demerouti, 2017).

As opposed to job demands, Demerouti et al. (2001) proposed that job resources are:

$[P]$ hysical, social, or organisational aspects of the job that may do any of the following: (a) be functional in achieving work goals; (b) reduce job demands and the associated physiological and psychological costs; (c) stimulate personal growth and development. (p. 501)

Job resources are found in organisations (e.g. job security or opportunities for advancement), interpersonal relations at work (e.g. team climate or supervisory and collegial support), the organisation of work (e.g. role clarity or participatory decision making) or in work tasks (e.g. task identity or task significance) (Bakker \& Demerouti, 2007).

Three years after Demerouti et al. (2001) introduced the JD-R model of burnout, Schaufeli and Bakker (2004) presented a revised version of the model by drawing from the principles of positive psychology (Seligman \& Csikszentmihalyi, 2000). This version of the JD-R model included employee engagement as a mediator variable. It no longer only sought to explain how job burnout develops but also the positive, fulfilling, work-related state known as employee engagement. The basic premise of this version of the JD-R model was that two parallel processes influence the level of strain (e.g. disengagement) or motivation (e.g. employee engagement) that employees experience and, in turn, their behaviour (e.g. job performance) (Bakker \& Demerouti, 2016). These processes are the health impairment process and the motivational process (Schaufeli \& Bakker, 2004). Research has demonstrated empirical support for both parallel processes (Bakker \& Demerouti, 2014; Simbula, 2010).
The health impairment process involves the physical and mental exhaustion associated with chronic job demands or poorly designed jobs. Under these circumstances, employees typically exhibit withdrawal behaviour to prevent further energy depletion and increased job stress (i.e. the motivational component of job burnout) (Bakker \& Demerouti, 2007). The motivational process, on the contrary, is associated with employee engagement, well-being and positive attitudes. Job resources play an intrinsic, as well as an extrinsic, motivational role in this process. In addition, job resources help employees to cope with job demands by buffering their influence on strain (Bakker \& Demerouti, 2007).

Following the inclusion of employee engagement as a mediator variable, the JD-R model was modified to account for personal resources. This modification acknowledged that employee behaviour is a function of the work environment (i.e. job demands and job resources) and personal factors. Xanthopoulou, Bakker, Demerouti and Schaufeli (2007, p. 124) defined personal resources as 'aspects of the self that are generally linked to resiliency and refer to individuals' sense of their ability to control and impact on their work environment successfully'. Examples of personal resources are optimism, organisation-based self-esteem and selfefficacy. Xanthopoulou et al. (2007) proposed that these malleable individual differences are activated by job resources and positively related to motivation (e.g. employee engagement), especially when job demands are high. Research has shown empirical evidence in support of the role of personal resources (e.g. Bakker \& Sanz-Vergel, 2013; Xanthopoulou, Bakker, \& Fischbach, 2013).

Next, Tims, Bakker and Derks (2013) proposed that job crafting should be integrated into the JD-R model to acknowledge the bottom-up perspective of job design in organisations. They defined job crafting as the process whereby employees proactively shape their job demands and job resources to optimise their work environment from the bottom up. Research has revealed that crafting behaviour aimed at increasing job resources (i.e. social and structural resources) and challenging job demands are positively related to motivation (e.g. employee engagement) (Tims, Bakker, \& Derks, 2012; Tims et al., 2013).

Even though JD-R theory has been revised following the inclusion of job crafting (Tims et al., 2013), these revisions are not germane to the study. The above-mentioned tenets lie central to the study. It will serve as a framework to aid in developing a conceptual model of the most salient antecedents of variance in employee engagement amongst public school teachers in the Western Cape.

\section{Research design Research approach}

In consideration of the research problem of the study and its objectives, the researchers decided to adopt the qualitative research approach, which has its basis in the interpretivist 
research paradigm. This approach to research is suitable when researchers desire to develop an in-depth understanding of the meaning of a particular phenomenon because not enough is known about it (Creswell, 2015). According to Babbie and Mouton (2001), it is generally used to describe and understand human behaviour.

\section{Research strategy}

The interactive qualitative analysis (IQA) methodology was adopted to generate, collect and analyse primary qualitative data (Northcutt \& McCoy, 2004). It is important to point out that the researchers deviated from the conventional IQA methodology. The IQA research process typically comprises four procedural steps, namely, 'research design, focus group, interview and report' (Northcutt \& McCoy, 2004, p. 44). Focus group sessions are used to identify categories of meaning, or affinities, and develop a visual representation of participants' experience with a particular phenomenon, known as a system influence diagram (SID). Because of unforeseen challenges associated with the arranged focus group sessions (e.g. time-constraints in teachers' schedules), the researchers opted for individual interviews (i.e. initial and follow-up). The data analyses were, however, performed strictly in accordance with the IQA methodology.

\section{Research method}

\section{Research setting}

The Western Cape comprises eight education districts (i.e. Eden and Karoo, Cape Winelands, Metro Central, Metro East, Metro North, Metro South, Overberg and West Coast). The setting of the study was mainstream public schools in the Cape Winelands education district. The Cape Winelands education district was selected, as it exemplifies the inequalities that exist within the South African education system, despite following the same curriculum.

The researchers decided to conduct the study at secondary public schools. This ensured that variations in the data generated were not attributable to different levels of schools (i.e. primary public schools versus secondary public schools), as this lies beyond the scope of the study.

\section{Entering the research setting and establishing researcher roles}

Participants were recruited once the study was evaluated and approved by the Ethics Committee of the university where it was undertaken and the Western Cape Department of Education. The researchers' primary concern with the recruitment of participants related to the commitment of principals and teachers to the objectives of the study. A twostage procedure was used to enter the research setting and establish researcher roles to address this concern.

The first stage was targeted at the recruitment of mainstream public schools in the Cape Winelands education district. The principal researcher established contact with principals from selected public schools telephonically. During the telephonic discussion, the principal researcher introduced herself and provided a brief explanation of the study and the nature of participation. Thereafter, the institutional permission form was sent to principals by email. Principals, who expressed interest in participating in the study, were asked to return a signed copy of the institutional permission form by email. The principal researcher scheduled a face-toface meeting with principals who preferred to discuss the participation of their school in person. In these instances, principals were asked to sign a hard copy of the institutional permission form.

Once principals granted institutional permission, the second stage commenced. This stage was targeted at the recruitment of teachers. Principals, who granted institutional permission, were asked to make an announcement during the weekly staff meeting to inform teachers about the study and demonstrate their support of participation in principle. Following this, the principal researcher visited participating public schools at a time that was convenient for its teachers to provide a detailed explanation of the study and the nature of participation. Teachers, who were interested in participating in the study, were invited to write their name, surname and contact details (i.e. email and telephone number) on an attendance record. Subsequently, the principal researcher contacted the teachers, who expressed an interest in participating in the study, individually to ask whether they had any further questions and concerns regarding their participation and wanted to be included in the sample group. As an alternative, the principal researcher distributed her contact details amongst teachers who preferred not to write their name, surname and contact details on an attendance record, but rather to contact the principal researcher personally to express an interest in participating in the study.

Participation in initial interviews did not obligate the teachers to participate in follow-up interviews. Once the initial interviews were completed, teachers were invited to engage in one follow-up interview.

\section{Sampling}

A non-probability sampling design, specifically purposive sampling, was used in the study. Babbie and Mouton (2001, p. 166) explained that the purposive sampling design is 'based on your judgement and the purpose of the study'. In accordance with this, only secondary school teachers employed in mainstream public schools located in the Western Cape Province, specifically the Cape Winelands education district, who have been teaching full-time for 1 year or more, were selected to participate in the study. This sampling design enabled the researchers to also purposefully select participants according to the criteria of 'distance and power' (i.e. proximity to and understanding of the phenomenon under investigation) (Northcutt \& McCoy, 2004, p. 69), who were able to provide an insider perspective on matters that are of central importance to the research problem of the study and its objectives. 
The principal researcher established contact with principals of 20 mainstream secondary public schools in Cape Winelands education district. Twelve principals agreed to participate in the study (response rate, 60\%). Thirty-seven teachers participated in initial interviews, whilst 28 teachers participated in follow-up interviews. Only participants who participated in initial interviews were invited to participate in followup interview. Initial (i.e. phase 1) and follow-up (i.e. phase 2) interviews were conducted until they no longer introduced new ideas and concepts, at which point data saturation was reached (Faulkner \& Trotter, 2017). In accordance with the national quintile system, public school teachers from fee schools (i.e. quintiles 4 and 5) (initial interviews: $n=20$ [54\%]; follow-up interviews: $n=14$ [50\%]) and no-fee schools (i.e. quintiles 1 and 2) (initial interviews: $n=17$ [46\%]; follow-up interviews: $n=14$ [50\%]) were included in the sample (Henderson, 2016).

Table 1 shows a description of the demographic and employment characteristics of participants. Data also showed that an equal number of participants' tenure was below 5 years $(n=10[27 \%])$, between 6 and 15 years $(n=10$ [27\%]) or between 16 and 25 years $(n=10$ [27\%]) during the initial interviews and the majority of participants' tenure was between 6 and 15 years $(n=10$ [36\%]) during the follow-up interviews. Moreover, the majority of participants were appointed as a class teacher (initial interviews: $n=31[84 \%]$; follow-up interviews: $n=24$ [86\%]).

\section{Data collection methods}

Two phases of data collection were conducted. Phase 1 involved initial interviews that were used to identify the most salient antecedents of variance in employee engagement amongst public school teachers (i.e. axial coding). Phase 2 involved follow-up interviews that were used to explore the relational dynamics that exist amongst these antecedents (i.e. theoretical coding).

Interviews were conducted at a time and place that was comfortable and convenient to participants. This prevented any interference with time spent teaching and helped to ensure that participants felt safe and relaxed during interviews. The length of both interviews ranged from $30 \mathrm{~min}$

TABLE 1: Demographic and employment characteristics of participants.

\begin{tabular}{|c|c|c|c|c|}
\hline \multirow[t]{2}{*}{ Description } & \multicolumn{4}{|c|}{ Number of participants } \\
\hline & \multicolumn{2}{|c|}{ Part 1} & \multicolumn{2}{|c|}{ Part 2} \\
\hline \multicolumn{5}{|l|}{ Tenure } \\
\hline$<5$ years & 10 & $F, 8 ; N F, 2$ & 6 & $F, 4 ; N F, 2$ \\
\hline $6-15$ years & 10 & $F, 5 ; N F, 5$ & 10 & $F, 6 ; N F, 4$ \\
\hline $16-25$ years & 10 & $F, 0 ; N F, 10$ & 7 & $F, 0 ; N F, 7$ \\
\hline$\geq 26$ years & 7 & $F, 7 ; N F, 0$ & 5 & $F, 4 ; N F, 1$ \\
\hline \multicolumn{5}{|l|}{ Job title } \\
\hline Class teacher & 31 & $F, 16 ; N F, 15$ & 24 & $F, 12 ; N F, 12$ \\
\hline Head of the department & 5 & $F, 3 ; N F, 2$ & 4 & $F, 2 ; N F, 2$ \\
\hline Other positions & 1 & $F, 1 ; N F, 0$ & 0 & $F, 0 ; N F, 0$ \\
\hline
\end{tabular}

Source: Adapted from Vermooten, N. (2018). Variance in employee engagement among public school teachers in the Western Cape Province: An exploratory study. Unpublished doctoral dissertation. Stellenbosch University

F, fee school; NF, no-fee school. to $1 \mathrm{~h}$ and $30 \mathrm{~min}$. The majority of interviews took approximately $1 \mathrm{~h}$ to complete.

Affinity identification (Phase 1): Initial interviews: Participants were invited to engage in a guided imagery exercise that was developed specifically for the study. The content of the guided imagery exercise was based on information gathered during a review of the extant literature and a series of informal discussions with public school teachers prior to the commencement of the study. In addition, the researchers referred to guidelines given by Northcutt and McCoy (2004) and the guided imagery exercises of studies that also used the IQA methodology (Burton, 2015; Tabane, 2010).

Participants were asked to close their eyes, make themselves comfortable, take a few deep breaths and clear their minds. The exercise presented participants with three issue statements, which primed them to reflect on their thoughts and experiences that relate to the engagement phenomenon:

- What are the key aspects that influence your job experience?

- How do you cope with being a teacher?

- What personal attributes/resources enable you to cope with being a teacher?

Participants were given approximately $5 \mathrm{~min}$ to reflect on their thoughts and experiences to generate relevant ideas and concepts that relate to the engagement phenomenon. Once participants had exhausted their ideas and concepts, they were asked to write it on index cards to articulate their thoughts and experiences. Participants were allowed to use a word, phrase or sentence.

Relational dynamics amongst affinities (Phase 2): Followup interviews: Participants were invited to complete an affinity relationship table (ART). As opposed to the bipolar repertory grid technique (Fransella, Bell, \& Bannister, 2004), each statement in the ART offered an option that reflected the existence and direction of a causal relationship between two affinities (e.g. $\mathrm{A} \leftarrow \mathrm{B}$ or $\mathrm{A} \rightarrow \mathrm{B}$ ) or the absence of any relationship at all $(A<>\mathrm{B})$. As an example, in terms of the relationship between perceived workload and employee engagement, participants either opined that perceived workload influences employee engagement, employee engagement influences student-teacher relationships and interactions, or perceived workload and employee engagement are unrelated. The participants were not required to judge the strength of relationships - only its existence and direction.

Participants were given a comprehensive description of each affinity, as well as the ART. The principal researcher introduced participants to each affinity. Once participants had read and understood each description, they were asked to complete the ART by reflecting on the causal relationships amongst all the affinities. Participants were encouraged to provide a verbal hypothesis 'that reflects their experiences 
and that supports the cause-and-effect relationship' (Northcutt \& McCoy, 2004, p. 152) between affinity pairs in the form of a short 'if-then statement'.

\section{Recording of data}

With participants' permission, interviews were voicerecorded to ensure that participants' responses were accurately interpreted. The researchers recognised that it is difficult to anonymise voice-recordings. Voice-recordings were, therefore, only used for transcription purposes. During the transcription of voice-recordings, the names of participants were replaced with pseudonyms. Moreover, transcriptions were proofread to ensure that subtle clues that could be linked to specific participants, places or institutions were removed. One participant did not grant the principal researcher permission to record the interview. In this instance, handwritten notes were taken.

The hard copy documents that were used to record participants' personal data were anonymised. These documents were anonymised by removing the names of participants with Tippex and assigning pseudonyms in black ink.

The hard copy documents and voice-recordings were stored in an electronic password-protected format on the principal researcher's personal computer. Only the researchers had access to the documents and voice-recordings.

\section{Quality assurance of data}

Northcutt and McCoy (2004, p. 17) claimed that 'IQA is clearly favourable to theory, both from the point of view of inducing theory and of testing it'. The current researchers endorsed this notion. It provided a systemic, rigorous and accountable framework for qualitative inquiry. Participants were required to 'create their own quilt of meaning' (Northcutt \& McCoy, 2004, p. 43) by considering how affinities are related within a system through a number of procedural steps. These steps assured the quality of data that was generated, collected and analysed in the study. Firstly, an audit trail was created for every procedural step taken and decision made throughout the research process. Secondly, the procedural steps that were used during interviews addressed the power relationship that typically exists between researchers and participants. Despite deviating from the conventional IQA methodology, participants generated and analysed their own data with minimal external influence. Lastly, it enabled the researchers to conduct a systematic and thorough examination of all the iterations of the perceived causal relationships concerning the engagement phenomenon and its antecedents in Phase 2 (Northcutt \& McCoy, 2004).

\section{Reporting style}

The researchers deviated from the conventional style of reporting. Each successive procedural step taken throughout the research process was presented with its findings. The procedural steps and emerging findings are, therefore, interwoven.

\section{Procedural steps and associated findings} Affinity identification (Phase 1): Axial coding

After participants finished writing their ideas and concepts on index cards, the principal researcher read each idea and concept aloud and asked participants to clarify what is meant by it and how it relates to the engagement phenomenon (i.e. clarification stage). This eliminated any ambiguity or vagueness and offered insight into perceived causal relationships amongst the ideas and concepts.

Once all the initial interviews were completed, the researchers identified affinity groupings based on the ideas and concepts that participants had mentioned. The participants generated 147 ideas and concepts in the form of a word, phrase or sentence to capture their thoughts and experiences that relate to the engagement phenomenon. Box 1 shows examples of the comments that participants made in Phase 1 regarding the affinity of parental attitudes. Vermooten (2018) provides detailed coverage of the comments generated regarding all the identified affinities.

Thereafter, the researchers listened to the voice-recordings or read the handwritten notes twice to gain an impression of affinities that explain variance in employee engagement amongst teachers. Thematic analysis was used to identify affinity groupings whilst listening to the voice-recordings or reading the handwritten notes. Then, the researchers listened to the voice-recordings or reread the handwritten notes again to transcribe and cluster exemplars in accordance with the most salient affinity groupings (i.e. clustering stage).

BOX 1: Examples of teachers' comments regarding parental attitudes.

- 'Parents must be involved to create a learning environment'.

- 'It starts in the parental home'.

- 'Parents influence our job because education is built in three. You see that three-foot pot. The educator, the child and the parent. It makes it easy if the parent is involved in the education process'.

- 'If I might be honest, we are on our own. These are our kids. The parents are not there. We are on our own'.

- 'The parents here at school, of our children (refers to learners from no-fee schools), are not involved. We are the only people that are involved'.

- 'Sometimes they (refers to the parents of learners) are working against the school, even though they want their children to have a better life (after completing Grade 12)'

- 'It becomes very difficult to convince the child that education is important if that is not being enforced at home. You might be teaching a student, but they are thinking my parent has money and they did not even go to school. It becomes very, very difficult to motivate these students.

- 'If you give them homework, half the class will come with their books clean. They did not do their homework, which means their parents did not check their homework'.

- 'When it comes to homework and things, they (refers to the parents of learners) are not involved at all'.

- 'Parents come to collect reports... Some are not even interested in that'.

- 'When we have a parent evening... What I experience is... If you tell the parents that it starts at 19:30, some will be standing here at 19:00 already'.

- 'Some parents are involved'.

- 'The parents here are really involved'.

Source: Adapted from Vermooten, N. (2018). Variance in employee engagement among public school teachers in the Western Cape Province: An exploratory study. Unpublished doctoral dissertation. Stellenbosch University 
This process was repeated twice to enhance the credibility of the identified affinities.

Based on the information gathered during initial interviews, 11 composite affinities were identified. The affinities are employee engagement, teaching motivation, personal characteristics, coping strategies, perceived workload, school climate, student-teacher relationships and interactions, school facilities and teaching resources, parental attitudes, social context of the neighbourhood and perceived organisational justice.

The researchers were satisfied with the affinity groupings; they generated a comprehensive description for each of the affinities mentioned above, as shown in Table 2. These descriptions were grounded in the information gathered during initial interviews. The researchers ensured that the descriptions were easily understandable to facilitate comprehension amongst participants. Jargon was avoided.

Member-checking was used to enhance the credibility of identified affinity groupings (Anney, 2014). In this regard, the principal researcher presented the comprehensive description for each of the affinities to participants before proceeding with part 2 to determine whether they could recognise and associate with the identified affinity groupings.

\section{Relational dynamics amongst affinities (Phase 2): Theoretical coding}

After participants completed the ART, the number of votes that each affinity pair relationship received was calculated on a spreadsheet in Microsoft Excel and sorted in descending order. Once the distribution of votes between affinity pairs was determined, the Pareto protocol was performed to identify the optimal number of relationships that should be included in the inter-relationship diagram (IRD) and resultant SID to explain the maximum amount of variance in the system.

The Pareto protocol is based on the principle that 'A minority of the relationships in any system will account for a majority of the variation within the system' (Northcutt \& McCoy, 2004, p. 157). The Pareto protocol was performed by calculating the cumulative totals and percentages of each affinity pair relationship in Microsoft Excel. Data indicated that power reached a maximum (21.39) at 55 relationships, which accounted for $50 \%$ of the variance in the system. The first 55 affinity pair relationships were, therefore, included in the IRD.

To develop the IRD, as shown in Figure 1, the affinity pair relationships that were included in the ART were mapped. Arrows were used to indicate the direction of the perceived causal relationships amongst all the affinities. Upward-facing arrows indicated that the row influenced the column and leftfacing arrows indicated that the column influenced the row. Because affinities cannot influence themselves, grey blocks were used as placeholders in the IRD.
TABLE 2: A comprehensive description of affinities.

\begin{tabular}{|c|c|}
\hline Affinity name & Comprehensive description \\
\hline Employee engagement & $\begin{array}{l}\text { The extent to which I feel focused in and enthusiastic } \\
\text { about teaching and wilfully go the extra mile, even when } \\
\text { faced with work challenges }\end{array}$ \\
\hline Teaching motivation & $\begin{array}{l}\text { The extent to which I became a teacher because I had a } \\
\text { calling to teach and wanted to make a difference in the } \\
\text { lives of others }\end{array}$ \\
\hline \multirow[t]{3}{*}{ Personal characteristics } & $\begin{array}{l}\text { Emotional intelligence: The extent to which I can } \\
\text { recognise my own emotions and those of others. The } \\
\text { extent to which I understand what causes emotions and } \\
\text { how they develop and change during an emotional } \\
\text { experience. The extent to which I can use this insight to } \\
\text { improve my thinking and behaviourz }\end{array}$ \\
\hline & $\begin{array}{l}\text { Psychological capital: The extent to which I am confident } \\
\text { in my ability to teach and able to bounce back from work } \\
\text { challenges to achieve work goals. The extent to which I } \\
\text { can look at the bright side, even when faced with work } \\
\text { challenges }\end{array}$ \\
\hline & $\begin{array}{l}\text { Work locus of control: The extent to which I am in control } \\
\text { of work outcomes }\end{array}$ \\
\hline Coping strategies & $\begin{array}{l}\text { The extent to which I rely on behavioural and cognitive } \\
\text { approaches to master, tolerate or reduce stress associated } \\
\text { with work challenges }\end{array}$ \\
\hline Perceived workload & $\begin{array}{l}\text { The extent to which my work (i.e. teaching and non-core } \\
\text { activities) is manageable in terms of its amount and } \\
\text { difficulty. The extent to which all my tasks are necessary or } \\
\text { reasonable }\end{array}$ \\
\hline School climate & $\begin{array}{l}\text { The extent to which the principal of my school is fair, } \\
\text { open to the inputs of others and sets clear expectations. } \\
\text { The extent to which the teachers at my school are } \\
\text { competent, committed to learners and respectful of } \\
\text { each other }\end{array}$ \\
\hline $\begin{array}{l}\text { Student-teacher } \\
\text { relationships and } \\
\text { interactions }\end{array}$ & $\begin{array}{l}\text { The extent to which I experience warmth and open } \\
\text { communication with learners at my school, without them } \\
\text { being over-reliant on me. The extent to which learners at } \\
\text { my school are well behaved }\end{array}$ \\
\hline $\begin{array}{l}\text { School facilities and } \\
\text { teaching resources }\end{array}$ & $\begin{array}{l}\text { The extent to which the physical structure of my school } \\
\text { (e.g. classrooms, staffroom and offices, ablution facilities, } \\
\text { laboratories, sports fields or fencing) and its teaching } \\
\text { resources (e.g. instructional material and equipment or IT } \\
\text { and other electronic infrastructure) are conducive to } \\
\text { teaching and learning processes }\end{array}$ \\
\hline Parental attitudes & $\begin{array}{l}\text { The extent to which parents or next of kin of learners at } \\
\text { my school instil the value of education and mobilise } \\
\text { resources to support learner progression and } \\
\text { achievement. The extent to which parents or next of kin of } \\
\text { learners at my school wilfully participate in and support } \\
\text { school activities }\end{array}$ \\
\hline $\begin{array}{l}\text { Social context of the } \\
\text { neighbourhood }\end{array}$ & $\begin{array}{l}\text { The extent to which the basic needs of learners at my } \\
\text { school are met (e.g. safety and security, housing, } \\
\text { healthcare, nutrition or transport), and their household } \\
\text { composition, in terms of the number of caregiving adults } \\
\text { with whom they live (e.g. single-parent household, foster } \\
\text { care or child-headed household), promotes learner } \\
\text { progression and achievement }\end{array}$ \\
\hline $\begin{array}{l}\text { Perceived } \\
\text { organisational justice }\end{array}$ & $\begin{array}{l}\text { The extent to which decision-making processes of larger } \\
\text { governing bodies regarding school-related matters are fair } \\
\text { and transparent. The extent to which individuals affected } \\
\text { by these decisions are treated with dignity and respect. } \\
\text { The extent to which resources are distributed fairly } \\
\text { amongst schools in my education district }\end{array}$ \\
\hline
\end{tabular}

Source: Adapted from Vermooten, N. (2018). Variance in employee engagement among Source: Adapted from Vermooten, N. (2018). Variance in employee engagement among public school teachers in the Western Cape
doctoral dissertation. Stellenbosch University

Once the IRD was developed, delta values were calculated by subtracting the number of left-facing arrows from the number of upward-facing arrows to determine the position of affinities in the SID. Thereafter, affinities were sorted in descending order in terms of delta frequency to identify drivers (i.e. primary and secondary), pivots and outcomes (i.e. primary and secondary). Positive delta values are drivers or causes, whereas negative delta values are outcomes or effects. Pivots are affinities that have an equal number of leftfacing arrows and upward-facing arrows. These affinities equally influence and are influenced by other affinities (Northcutt \& McCoy, 2004).

Figure 1 shows that three primary drivers (i.e. perceived organisational justice, social context of the neighbourhood 


\begin{tabular}{|l|l|l|l|l|l|l|l|l|l|l|l|l|l|l|l|}
\hline Affinities & POJ & SCN & PC & TM & SFTR & CS & EE & PA & PW & SC & STRI & Outs & Ins & $\Delta$ & Position in the SID \\
\hline POJ & & $\leftarrow$ & $\uparrow$ & $\uparrow$ & $\uparrow$ & $\uparrow$ & $\uparrow$ & $\uparrow$ & $\uparrow$ & $\uparrow$ & $\uparrow$ & 9 & 1 & 8 & Primary driver \\
\hline SCN & $\uparrow$ & & $\leftarrow$ & $\uparrow$ & $\uparrow$ & $\uparrow$ & $\uparrow$ & $\uparrow$ & $\uparrow$ & $\uparrow$ & $\uparrow$ & 9 & 1 & 8 & Primary driver \\
\hline PC & $\leftarrow$ & $\uparrow$ & & $\uparrow$ & $\uparrow$ & $\uparrow$ & $\uparrow$ & $\uparrow$ & $\uparrow$ & $\uparrow$ & $\uparrow$ & 9 & 1 & 8 & Primary driver \\
\hline TM & $\leftarrow$ & $\leftarrow$ & $\leftarrow$ & & $\uparrow$ & $\uparrow$ & $\uparrow$ & $\uparrow$ & $\uparrow$ & $\uparrow$ & $\uparrow$ & 7 & 3 & 4 & Driver \\
\hline SFTR & $\leftarrow$ & $\leftarrow$ & $\leftarrow$ & $\leftarrow$ & & $\uparrow$ & $\uparrow$ & $\leftarrow$ & $\uparrow$ & $\uparrow$ & $\uparrow$ & 5 & 5 & 0 & Pivot \\
\hline CS & $\leftarrow$ & $\leftarrow$ & $\leftarrow$ & $\leftarrow$ & $\leftarrow$ & & $\uparrow$ & $\uparrow$ & $\uparrow$ & $\uparrow$ & $\uparrow$ & 5 & 5 & 0 & Pivot \\
\hline EE & $\leftarrow$ & $\leftarrow$ & $\leftarrow$ & $\leftarrow$ & $\leftarrow$ & $\leftarrow$ & & $\uparrow$ & $\leftarrow$ & $\uparrow$ & $\uparrow$ & 3 & 7 & -4 & Outcome \\
\hline PA & $\leftarrow$ & $\leftarrow$ & $\leftarrow$ & $\leftarrow$ & $\uparrow$ & $\leftarrow$ & $\leftarrow$ & & $\uparrow$ & $\leftarrow$ & $\uparrow$ & 3 & 7 & -4 & Outcome \\
\hline PW & $\leftarrow$ & $\leftarrow$ & $\leftarrow$ & $\leftarrow$ & $\leftarrow$ & $\leftarrow$ & $\uparrow$ & $\leftarrow$ & & $\uparrow$ & $\uparrow$ & 3 & 7 & -4 & Outcome \\
\hline SC & $\leftarrow$ & $\leftarrow$ & $\leftarrow$ & $\leftarrow$ & $\leftarrow$ & $\leftarrow$ & $\leftarrow$ & $\uparrow$ & $\leftarrow$ & & & 1 & 9 & -8 & Primary outcome \\
\hline STRI & $\leftarrow$ & $\leftarrow$ & $\leftarrow$ & $\leftarrow$ & $\leftarrow$ & $\leftarrow$ & $\leftarrow$ & $\leftarrow$ & $\leftarrow$ & $\uparrow$ & & 1 & 9 & -8 & Primary outcome \\
\hline
\end{tabular}

Source: Adapted from Vermooten, N. (2018). Variance in employee engagement among public school teachers in the Western Cape Province: An exploratory study. Unpublished doctoral dissertation. Stellenbosch University

POJ, perceived organisational justice; SCN, social context of the neighbourhood; PC, personal characteristics; TM, teaching motivation; SFTR, school facilities and teaching resources; CS, coping strategies; EE, employee engagement; PA, parental attitudes; PW, perceived workload; SC, school climate; STRI, student-teacher relationships and interactions; $\Delta$, delta values; SID, system influence diagram.

FIGURE 1: Inter-relationship diagram in descending order.

and personal characteristics), one driver (i.e. teaching motivation), two pivots (i.e. school facilities and teaching resources and coping strategies), three outcomes (i.e. employee engagement, parental attitudes and perceived workload) and two primary outcomes (i.e. school climate and studentteacher relationships and interactions) were identified.

After drivers, pivots and outcomes were identified, the Inspiron software package (Northcutt \& McCoy, 2004) was used to create the SID. Affinities were positioned in accordance with the above-mentioned SID assignments (i.e. drivers, pivots and outcomes). Firstly, primary drivers were arranged on the left-hand side and primary outcomes on the right-hand side. Thereafter, secondary drivers and outcomes were positioned between primary drivers and primary outcomes with drivers placed on the left-hand side and outcomes on the right-hand side. Thirdly, pivots were positioned at the centre of the SID. Lastly, arrows were drawn to reflect the direction of each affinity pair relationship in the IRD.

The first version of the SID is known as the cluttered SID. This version of the SID was saturated with all the affinity pair relationships included in the IRD. Even though it offered a visual representation of the entire system of drivers and outcomes and was rich in terms of its descriptive capability, the cluttered SID could not be used as an interpretive device. It was too complicated to be meaningful. In consideration of the fact that comprehensiveness and parsimony were objectives of the SID, redundant pathways were deleted to construct the uncluttered SID process flow, as shown in Figure 2. Redundant pathways are paths that, even if deleted, the pathway from the driver to the outcome would still be achieved through an intermediary affinity (Northcutt \& McCoy, 2004). By deleting redundant pathways, the researchers were able to simplify the system and optimise its explanatory power.

Feedback loops consist of 'at least three affinities, each influencing the other directly or indirectly' (Northcutt \& McCoy, 2004, p. 355). Inspection of the uncluttered SID revealed two feedback loops. The first feedback loop composed of the social context of the neighbourhood, perceived organisational justice and personal characteristics. This feedback loop subsumed the interaction between teachers themselves and social, as well as institutional, influences. The second feedback loop composed of coping strategies, perceived workload, employee engagement, student-teacher relationships and interactions, school climate, parental attitudes and school facilities and teaching resources. This feedback loop also subsumed the interaction between teachers themselves and institutional influences. However, these institutional influences related to the internal functioning of schools.

Each feedback loop was renamed by reviewing its components through the process of zooming. The substitute names that were created for the subsystems mentioned above are socio-institutional influences (i.e. first feedback loop) and intra-institutional influences (i.e. second feedback loop). These 'super affinities' were used to replace the feedback loops in the zoomed out uncluttered SID, as shown in Figure 3 (Northcutt \& McCoy, 2004, p. 355). Figure 3 is identical to Figure 2, except that the feedback loops were collapsed or zoomed out into terms that are more general. 
(1) Teachers' personal characteristics influence their perception of the social context of the neighbourhood

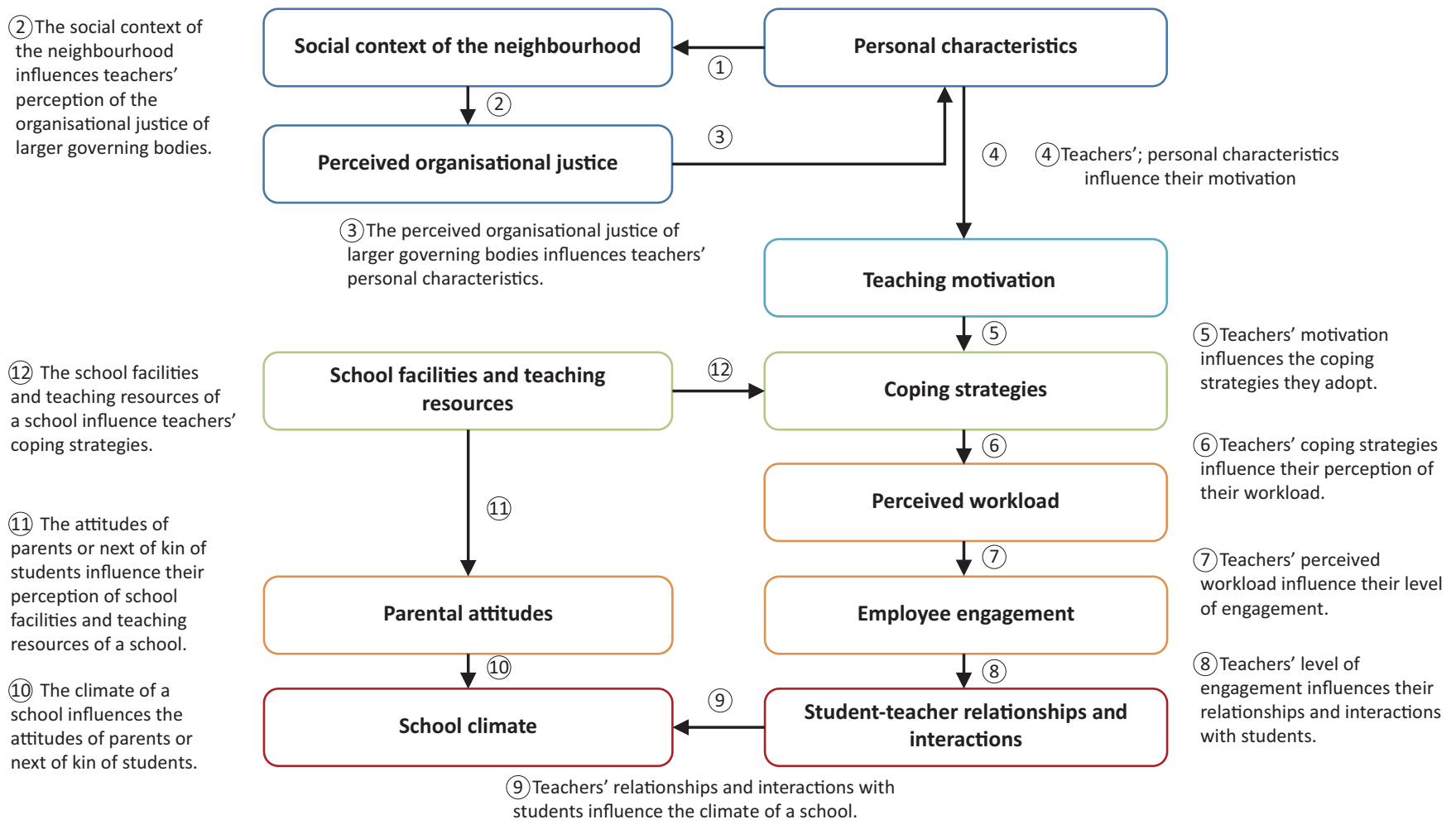

Source: Adapted from Vermooten, N. (2018). Variance in employee engagement among public school teachers in the Western Cape Province: An exploratory study. Unpublished doctoral dissertation. Stellenbosch University

FIGURE 2: Theoretical summary of the uncluttered systems influence diagram process flow.

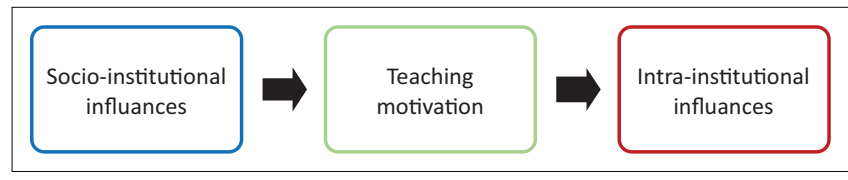

Source: Adapted from Vermooten, N. (2018). Variance in employee engagement among public school teachers in the Western Cape Province: An exploratory study. Unpublished doctoral dissertation. Stellenbosch University.

FIGURE 3: Zoomed out systems influence diagram.

\section{Discussion}

Motshekga reported that more than $80 \%$ of public schools in South Africa are labelled as 'dysfunctional' (Wilkinson, 2015). To offer all South Africans quality basic education, wellfunctioning teachers, who are able and motivated to perform their job optimally, are required (e.g. Fouché, Rothmann, \& Van Der Vyver, 2017; Janik \& Rothmann, 2015). The primary objective of the study was to develop a conceptual model of the most salient antecedents of variance in employee engagement amongst public school teachers in the Western Cape.

\section{Summary of the emerging conceptual model}

The uncluttered SID, as shown in Figure 2, offers a visual representation of teachers' experiences with the engagement phenomenon. According to Northcutt and McCoy (2004), the visual representation represents a journey, which begins with the primary drivers and ends with the primary outcomes. The researchers supplemented the uncluttered SID with a theoretical summary to ensure that the dynamics of the journey are communicated clearly. The theoretical summary will be discussed below. In accordance with the feedback loops that were identified during the process of zooming, the theoretical summary will be divided into three parts.

Feedback loops comprise 'at least three affinities, each influencing the other directly or indirectly' (Northcutt \& McCoy, 2004, p. 355). The feedback loops that were identified are socio-institutional influences, teaching motivation and intra-institutional influences. The researchers named the feedback loops by reviewing the comprehensive descriptions of the affinities that are subsumed under each feedback loop, as well as its position within the overall system.

The first part of the theoretical summary comprises socioinstitutional influences. Figure 2 shows that teachers' personal characteristics influence their perception of the social context of the neighbourhood. Teachers, who exhibit high emotional intelligence, positive psychological capital and an internal locus of control (i.e. personal characteristics), will be more likely to address challenges associated with the social context of the neighbourhood. However, the social context of the neighbourhood influences teachers' perception of the organisational justice of larger governing bodies. When the basic needs of learners are met, and their household composition promotes learner progression and achievement, teachers will be more likely to perceive larger governing bodies as fair and transparent. These perceptions, 
in turn, influence teachers' personal characteristics. Teachers, who perceive larger governing bodies as fair and transparent, will be more likely to exhibit high emotional intelligence, positive psychological capital and an internal locus of control (i.e. personal characteristics). The latter finding coincides with the findings of Judge, Bono and Locke (2000), whilst the preceding ones could be seen as fairly novel findings specific to the current study.

The second part of the theoretical summary is centred on teaching motivation. Figure 2 shows that teachers' personal characteristics influence their motivation to pursue a career in teaching. Teachers, who exhibit high emotional intelligence, positive psychological capital and an internal locus of control (i.e. personal characteristics), will be more likely to feel called to pursue a career in teaching. Teachers' motivation to pursue a career in teaching, in turn, influences the coping strategies that they adopt when work challenges arise. Teachers, who feel called to teach, will be more likely to adopt adaptive coping strategies in response to work challenges. These findings are compatible with the findings of Richardson and Watt (2006).

The third part of the theoretical summary comprises intra-institutional influences. Teachers' coping strategies influence their perception of their workload. Teachers, who adopt adaptive coping strategies, will be more likely to feel that their work is manageable in terms of its amount and difficulty. This perception, in turn, influences teachers' level of engagement. Teachers, who feel that their work is manageable in terms of its amount and difficulty, will be more likely to exhibit vigour, dedication and absorption (i.e. employee engagement). These findings are compatible with the findings of Van den Broeck et al. (2008). Teachers' level of engagement influences their relationships and interactions with learners. Teachers, who exhibit vigour, dedication and absorption (i.e. employee engagement), will be more likely to experience warmth and open communication with learners. The research of Frenzel, Goetz, Stephens and Jacob (2009) and Klassen, Perry and Frenzel (2012) supports this relationship. Teachers' relationships and interactions with learners, in turn, influence the climate of a school. When teachers experience warmth and open communication with learners, the teachers of a school will be more likely to be competent and committed to learners. Along the same lines, its principal will be more likely to be open to the inputs of others and set clear expectations. The climate of a school influences the attitudes of parents and next of kin of learners. When the teachers of a school are competent and committed to learners and its principal is open to the inputs of others and sets clear expectations, parents or next of kin of learners will be more likely to instil the value of education, mobilise resources to support learners' progression and achievement and wilfully participate in and support school activities. The attitudes of parents and next of kin of learners, in turn, influence teachers' perception of school facilities and teaching resources. When parents or next of kin of learners instil the value of education, mobilise resources to support learner progression and achievement and wilfully participate in and support school activities, it is more likely that teachers will perceive the physical structure of a school and its teaching resources as conducive to learning. The school facilities and teaching resources, in turn, influence teachers' coping strategies. When the physical structure of a school and its teaching resources are conducive to learning, teachers will be more likely to adopt adaptive coping strategies when work challenges arise. Whilst some of these findings are fairly novel, the positive relationship between school climate and teacher psychological wellbeing, which manifests in many different ways, has been supported by the work of Sisask et al. (2014).

The researcher notes that it should be borne in mind that the causal interpretations of the linkages between the variables are how the teachers perceive it to be, which should be verified in further research, although it might turn out to be bidirectional in nature.

\section{Application of the ecological systems theory}

The researchers suggested that the affinities that were identified during interviews include latent variables that emanate from teachers themselves and those that emanate from the environment. This corresponds with Bronfenbrenner's (1977) ecological systems theory. The ecological systems theory proposes that human development is best understood by mapping the interaction between individuals and the environment that surrounds them. It was, therefore, used to frame the affinities, as shown in Figure 4.

The ecological systems theory refers to five nested and interconnected structures, ranging from the microsystem to

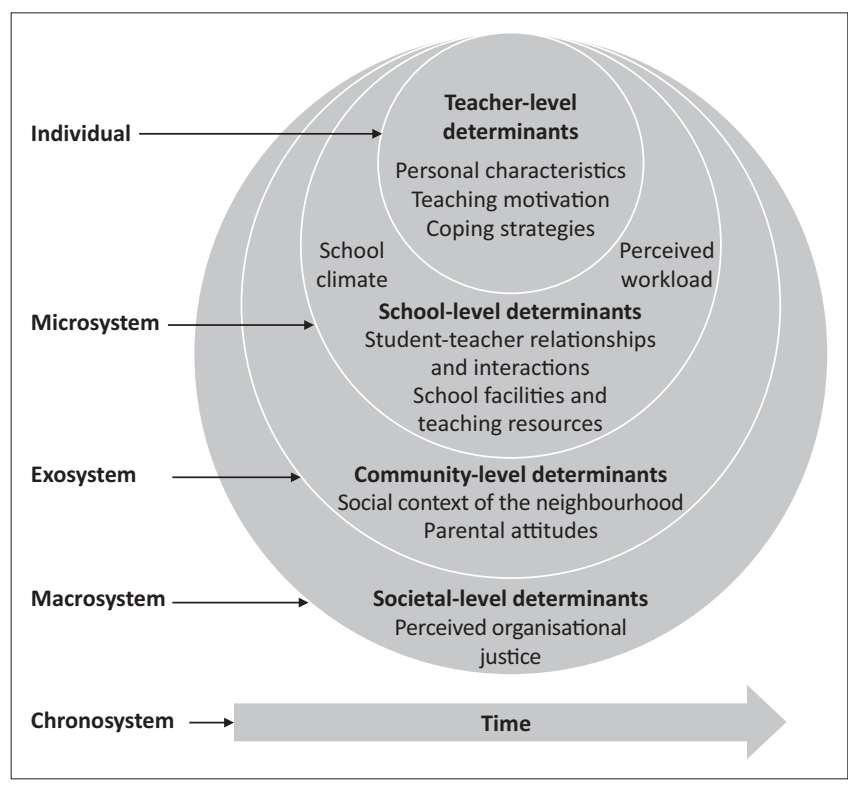

Source: Adapted from Newacheck, P.W., Rising, J.P. and Kim, S.E. (2006). Children at risk for special health care needs. Pediatrics, 118(1), 338

FIGURE 4: Ecological systems theory application. 
the macrosystem (Bronfenbrenner, 1977). The researchers referred to each of these structures, apart from the mesosystem, to map the interactions between teachers and the environment that surrounds them. The mesosystem comprises linkages and processes that occur between two or more settings. Each of these settings contains individuals. The mesosystem is, therefore, made up of various microsystems. Even though there were participants who referred to the interaction between work and family conditions and processes during initial interviews, the majority of participants did not refer to other microsystems, apart from their school (i.e. workplace). In consideration of this, the researchers did not examine how demanding and resourceful aspects of one microsystem influences outcomes in another microsystem in the study.

\section{Teacher-level determinants}

The inner structure represents individuals themselves. According to Bronfenbrenner (1977), individuals have personal attributes that invite, inhibit or prevent engagement and interaction with the environment that surrounds them. The researchers suggested that the inner structure represents teachers themselves and subsumes teacher-level determinants of employee engagement. Based on the findings obtained during interviews, teacher-level determinants include teaching motivation, personal characteristics (i.e. psychological capital, emotional intelligence and work locus of control) and coping strategies. Within the parameters of the JD-R theory, these antecedents signify personal resources (Xanthopoulou et al., 2007) and coping strategies (Tims et al., 2012).

\section{School-level determinants}

Thesecond nested structure is the microsystem. Bronfenbrenner (1977) explained that the microsystem refers to the pattern of activities, social roles and interpersonal relationships that individuals encounter in specific face-to-face settings. The researchers proposed that the microsystem refers to the pattern of activities, social roles and interpersonal relationships that teachers encounter in their school and subsumes school-level determinants of employee engagement. Based on the findings obtained during interviews, school-level determinants include school climate, perceived workload, student-teacher relationships and interactions and school facilities and teaching resources. Within the parameters of the JD-R theory, these antecedents denote job demands (i.e. perceived workload) and job resources (i.e. school climate, studentteacher relationships and interactions and school facilities and teaching resources) (Demerouti et al., 2001).

\section{Community-level determinants}

The third nested structure is the exosystem. According to Bronfenbrenner (1977), the exosystem comprises linkages and processes that occur between two or more settings. Even though only one setting may contain individuals, he advocated that events that occur in other settings might influence conditions and processes in their immediate setting.
The researchers proposed that the exosystem comprises linkages and processes that occur between the teachers' school (i.e. workplace) and the surrounding community and subsumes community-level determinants of employee engagement. Based on the findings obtained during interviews, community-level determinants include the social context of the neighbourhood and parental attitudes. These antecedents could not be classified within the parameters of the JD-R theory (Demerouti et al., 2001). It was proposed that the demand and resource dimensions of the JD-R theory should be broadened.

In line with most models and theories of job stress and motivation, the JD-R theory differentiates between personal, as well as job, demands and resources. However, with reference to the findings obtained during interviews, the researchers highlighted the importance of recognising that contextual demands and resources emanate from external environments, such as the surrounding community. This corresponds with recent research about the way in which context influences employee engagement and its antecedents (e.g. Jenkins \& Delbridge, 2013; Rothmann, 2014). By extrapolating from recent research, the researchers recommended that the abovementioned community-level determinants signify contextual resources.

\section{Societal-level determinants}

The fourth nested structure is the macrosystem. Bronfenbrenner (1977) explained that the macrosystem refers to overarching patterns of microsystem, mesosystem and exosystem characteristics associated with particular cultures or subcultures (e.g. belief systems, bodies of knowledge and customs). It signifies the 'social blueprint for a particular culture, subculture or other broader social context', which influences conditions and processes in microsystems (Bronfenbrenner, 2005, p. 150). The researchers proposed that the macrosystem extends beyond the linkages and processes that occur between teachers' school (i.e. workplace) and the surrounding community. It comprises the socio-political framework that influences conditions and processes in teachers' school (i.e. workplace) and subsumes societal-level determinants of employee engagement. Based on the findings obtained during interviews, perceived organisational justice is a societal-level determinant. Along with community-level determinants, this determinant could not be classified within the parameters of the JD-R theory (Demerouti et al., 2001). Even though perceived organisational justice influences the pattern of activities, social roles and interpersonal relationships that teachers encounter in their school (i.e. job demands and job resources), it emanates from the external environment. In line with the preceding discussion, the researchers recommended that it signifies a contextual resource.

\section{Managerial implications}

The findings of the study hold inevitable consequences for human resources practices and interventions in the education context. 


\section{Teacher-level implications}

The researchers recommend that it is important to remain conscious of teacher-level determinants during the recruitment and selection of graduates who intend to study towards a bachelor's degree or postgraduate diploma in education and qualified teachers. In addition, the researchers recommend that personal characteristics and coping strategies of students and qualified teachers should be developed through training interventions (Luthans, Luthans, \& Avey, 2014). In terms of teaching motivation, the researchers suggest aspiring teaching students should receive access to career counselling services to assist them in identifying their calling prior to enrolling for a bachelor's degree or postgraduate diploma in education (Dik \& Duffy, 2009).

\section{School-level implications}

By extrapolating from Hoy, Tarter, and Kottkamp's (1991) conceptualisation of school climate, the researchers propose that principals and teachers influence the climate of a school. In consideration of this, they advise that principals and teachers should undergo training to develop attributes that foster collegial leadership and teacher professionalism respectively (Darling-Hammond, LaPointe, Meyerson, Orr, \& Cohen, 2007). In addition, the researchers recommend that principals and teachers should have access to coaching services (Goff, Edward Guthrie, Goldring, \& Bickman, 2014)

The researchers anticipated that challenges associated with student-teacher relationships and interactions would partly be addressed by the training interventions mentioned above. Similarly, challenges associated with perceived workload and school facilities and teaching resources would partly be addressed by adopting a participative intervention approach, as discussed below.

\section{Community-level implications}

Whilst a desirable strategy may be to make public schools less susceptible to the contextual demands imposed by community-level determinants, this is not feasible. Instead, the researchers recommend that it is imperative to prepare students who are studying towards a bachelor's degree or postgraduate diploma in education to cope with the contextual demands imposed by community-level determinants through increased teaching practice during education programmes.

\section{Societal-level implications}

The researchers recommend that the leaders and managers of larger governing bodies should identify the determinants of teachers' perception of organisational justice through a participative intervention. This approach is based on the search conference method, whereby employees share their thoughts and inputs concerning organisational justice planning and decision-making processes (Linna et al., 2011).
In addition to a participative intervention, the researchers recommend that the leaders and managers of larger governing bodies must receive management training in organisational justice to enhance teachers' perception of organisational justice (Nakamura et al., 2016).

\section{Limitations of the study and recommendations for future research}

Firstly, the relational dynamics that exist amongst personal characteristics were not explored during follow-up interviews. Psychological capital, emotional intelligence and work locus of control were subsumed in a single affinity, namely, personal characteristics. Future research should operationalise psychological capital, emotional intelligence and work locus of control separately to gain an understanding of the relational dynamics that exist amongst personal characteristics.

Secondly, the study did not examine how demanding and resourceful aspects of one microsystem influences outcomes in another microsystem (Bronfenbrenner, 1977). The researchers recognise that it may be insightful to examine the linkages and processes that occur between two or more settings. As an illustration, to gain an understanding of the way in which the interaction between work (i.e. job demands and job resources) and family (i.e. family demands and family resources) conditions and processes influence employee engagement amongst teachers. Future research should, therefore, examine how demanding and resourceful aspects of one microsystem influences outcomes in another microsystem amongst teachers.

Thirdly, the study deviated from the conventional IQA methodology. Focus group sessions were replaced by individual interviews (i.e. initial and follow-up interviews). Whilst the researchers acknowledge that this deviation may have influenced the findings, this would need to be determined by further research.

\section{Conclusion}

This study contributed to scientific knowledge by offering insight into the most salient antecedents of variance in employee engagement amongst public school teachers in the Western Cape Province. Previous studies amongst teachers have not examined the combination of the contextual, organisational, job and individual antecedents of variance in employee engagement. The researchers recommended human resource practices and interventions that target each of the above-mentioned categories to nurture employee engagement amongst teachers and, in turn, address challenges with the quality of basic education offered in many public schools across South Africa.

\section{Acknowledgements}

The authors are thankful for the support received from the Western Cape Department of Education, as well as participating public schools and teachers. 


\section{Competing interests}

The authors have declared that no competing interests exist.

\section{Authors' contributions}

N.V. conducted the literature review, and coordinated the data collection, analysis and interpretation. N.V. and J.M. prepared the manuscript. J.M. and B.B. were the study leaders of this project.

\section{Ethical consideration}

Ethical approval to conduct the study was obtained from the Research Ethics Committee: Human Research (Humanities) of Stellenbosch University (reference no. SU-HSD-002152) and the Department of Education, Western Cape Government (reference no. 20160224-8110).

\section{Funding information}

This research received no specific grant from any funding agency in the public, commercial or not-for-profit sectors.

\section{Data availability statement}

New data were created and analysed in this study. Authors may be contacted in this regard.

\section{Disclaimer}

The views and opinions expressed in this article are those of the authors and do not necessarily reflect the official policy or position of any affiliated agency of the authors.

\section{References}

Anney, V.N. (2014). Ensuring the quality of the findings of qualitative research: Looking at trustworthiness criteria. Journal of Emerging Trends in Educational Research and Policy Studies, 5(2), 272-281.

Babbie, E.R., \& Mouton, J. (2001). The practice of social science research. Cape Town Oxford University Press.

Bakker, A.B., \& Demerouti, E. (2007). The job demands-resources model: State of the art. Journal of Managerial Psychology, 22(3), 309-328. https://doi. org/10.1108/02683940710733115

Bakker, A.B., \& Demerouti, E. (2014). Job demands-resources theory. In P.Y. Chen \& C.L. Cooper (Eds.), Wellbeing: A complete reference guide: Work and wellbeing (Vol. 3, pp. 37-64). Chichester: Wiley-Blackwell. https://doi.org/ 10.1002/9781118539415.wbwell019

Bakker, A.B., \& Demerouti, E. (2017). Job demands-resources theory: Taking stock and looking forward. Journal of Occupational Health Psychology, 22(3), 273-285. https://doi.org/10.1037/ocp0000056

Bakker, A.B., \& Sanz-Vergel, A.I. (2013). Weekly work engagement and flourishing: The role of hindrance and challenge job demands. Journal of Vocational Behavior 83(3), 397-409. https://doi.org/10.1016/j.jvb.2013.06.008

Bernstein, A. (2015). Teacher in South Africa: Supply and demand 2013 to 2025. Johannesburg: Centre for Development and Enterprise.

Bronfenbrenner, U. (1977). Toward an experimental ecology of human development. American Psychologist, 32(7), 513-531. https://doi.org/10.1037/0003-066X.32.7.513

Bronfenbrenner, U. (2005). Making human beings human: Bioecological perspectives on human development. Thousand Oaks, CA: Sage.

Burton, R.S. (2015). Pursuing a child: An interactive qualitative analysis of the infertility treatment experience. Unpublished doctoral dissertation. University of Texas, Austin, TX.

Carnoy, M., Chisholm, L., \& Chilisa, B. (2012). The low achievement trap: Comparing schools in Botswana and South Africa. Cape Town: HSRC Press.

Cavanaugh, M.A., Boswell, W.R., Roehling, M.V., \& Boudreau, J.W. (2000). An empirical examination of self-reported work stress among US managers. Journal of Applied Psychology, 85(1), 65-74. https://doi.org/10.1037/0021-9010.85.1.65
Creswell, J.W. (2015). A concise introduction to mixed methods research. Thousand Oaks, CA: Sage.

Csikszentmihalyi, M. (1997). Finding flow: The psychology of engagement with everyday life. New York, NY: Basic Books.

Darling-Hammond, L. (2015). Want to close the achievement gap? Close the teaching gap. American Educator, 38(4), 14-18.

Darling-Hammond, L., LaPointe, M., Meyerson, D., Orr, M.T., \& Cohen, C. (2007). Preparing school leaders for a changing world: Lessons from exemplary leadership development programs. Stanford, CA: Stanford Educational Leadership Institute.

Demerouti, E., Bakker, A.B., Nachreiner, F., \& Schaufeli, W.B. (2001). The job demandsresources model of burnout. Journal of Applied Psychology, 86(3), 499-512. https://doi.org/10.1037//0021-9010.86.3.499

Dik, B.J., \& Duffy, R.D. (2009). Calling and vocation at work: Definitions and prospects for research and practice. The Counseling Psychologist, 37(3), 424-450. https:// doi.org/10.1177/0011000008316430

Faulkner, S.L., \& Trotter, S.P. (2017). Data saturation. In J. Matthes, C.S. Davis, \& R.F. Potter (Eds.), The International Encyclopedia of communication research methods. New York, NY:John Wiley\&Sons. https://doi.org/10.1002/9781118901731. iecrm0060

Fouché, E., Rothmann, S., \& Van Der Vyver, C. (2017). Antecedents and outcomes of meaningful work among school teachers. South African Journal of Industrial Psychology, 43(1), 1-10. https://doi.org/10.4102/sajip.v43i0.1398

Fransella, F., Bell, R., \& Bannister, D. (2004). A manual for repertory grid technique (2nd edn.). Chichester: John Wiley \& Sons.

Frenzel, A.C., Goetz, T., Stephens, E.J., \& Jacob, B. (2009). Antecedents and effects of teachers emotional experiences: An integrated perspective and empirical test. In P.A. Schutz \& M. Zembylas (Eds.), Advances in teacher emotion research: The impact on teachers' lives (pp. 129-151). Boston, MA: Springer.

Goff, P., Edward Guthrie, J., Goldring, E., \& Bickman, L. (2014). Changing principals' leadership through feedback and coaching. Journal of Educational Administration, 52(5), 682-704. https://doi.org/10.1108/JEA-10-2013-0113

Govender, P. (2016). It's not kids bunking - It's teachers. Retrieved from https://mg. co.za/article/2016-06-02-its-not-kids-bunking-its-teachers

Gqomo, A. (2017). SA teacher absenteeism rises from $8 \%$ to $10 \%$ daily. Retrieved from https://www.politicalanalysis.co.za/sa-teacher-absenteeism-rises-from-8to-10-daily/

Henderson, R. (2016). Quintile system perpetuates school inequality, Equal education says. Retrieved from https://www.timeslive.co.za/news/south-africa/2016-06 17-quintile-system-perpetuates-school-inequality-equal-education-says/

Higley, S. (2013). Education in South Africa - What education? Retrieved from http:// education-whateducation.blogspot.co.za/2013/10/teachers-resign-in-droves. $\mathrm{html}$

Hockey, G.R.J. (1997). Compensatory control in the regulation of human performance under stress and high workload: A cognitive-energetical framework. Biological Psychology, 45(1-3), 73-93. https://doi.org/10.1016/S0301-0511(96)05223-4

Howie, S.J., Combrink, C., Roux, K., Tshele, M., Mokoena, G., \& McLeod-Palane, N.M. (2016). Progress in International Reading Literacy Study (PIRLS) 2016: South African children's reading literacy achievement. Pretoria: Centre for Evaluation and Assessment, University of Pretoria.

Hoy, W.K., Tarter, C.J., \& Kottkamp, R.B. (1991). Open schools/healthy schools: Measuring organizational climate. Newbury Park, CA: Corwin Press.

Janik, M., \& Rothmann, S. (2015). Meaningful work and secondary school teachers' intention to leave. South African Journal of Education, 35(2), 1-13. https://doi. org/10.15700/SAJE.V35N2A1008

Jenkins, S., \& Delbridge, R. (2013). Context matters: Examining 'soft' and 'hard' approaches to employee engagement in two workplaces. International Journal of Human Resource Management, 24(14), 2670-2691. https://doi.org/10.1080/095 85192.2013.770780

Jimerson, S.R., \& Haddock, A.D. (2015). Understanding the importance of teachers in facilitating student success: Contemporary science, practice, and policy. School Psychology Quarterly, 30(4), 488-493. http://doi.org/10.1037/spq0000134

Judge, T.A., Bono, J.E., \& Locke, E.A. (2000). Personality and job satisfaction: The mediating role of job characteristics, Journal of Applied Psychology, 85(2), 237-249. https://doi.org/10.1037/0021-9010.85.2.237

Kahn, W.A. (1990). Psychological conditions of personal engagement and disengagement at work. Academy of Management Journal, 33(4), 692-724. https://doi.org/10.5465/256287

Klassen, R.M., Perry, N.E., \& Frenzel, A.C. (2012). Teachers' relatedness with students: An underemphasized component of teachers ' basic psychological needs. Journal of Educational Psychology, 104(1), 150-165. https://doi.org/10.1037/a0026253

LePine, J.A., Podsakoff, N.P., \& LePine, M.A. (2005). A meta-analytic test of the challenge stressor-hindrance stressor framework: An explanation for inconsistent relationships among stressors and performance. Academy of Management Journal, 48(5), 764-775. https://doi.org/10.5465/AMJ.2005.18803921

Linna, A., Väänänen, A., Elovainio, M., Kivimäki, M., Pentti, J., \& Vahtera, J. (2011) Effect of participative intervention on organisational justice perceptions: A quasiexperimental study on Finnish public sector employees. International Journal of Human Resource Management, 22(3), 706-721. https://doi.org/10.1080/095851 92.2011.543761

Luthans, B.C., Luthans, K.W., \& Avey, J.B. (2014). Building the leaders of tomorrow: The development of academic psychological capital. Journal of Leadership \& OrganizationalStudies, 21(2), 191-199. https://doi.org/10.1177/1548051813517003

Mampane, P.M. (2012). The teacher turnover crisis: Evidence from South Africa. Business Education \& Accreditation, 4(2), 73-83. 
Maphalala, M., \& Mpofu, N. (2019). South Africa must up its game and produce more teachers. Retrieved from https://theconversation.com/south-africa-must-up-itsteachers. Retrieved from $\mathrm{https}: / /$ theconvers

Maslach, C., \& Leiter, M.P. (1997). The truth about burnout: How organizations cause personal stress and what to do about it. San Francisco, CA: Jossey-Bass.

McKinsey, C., \& McKinsey, M.M. (2007). How the world's best-performing school systems come out on top. London: McKinsey.

Nakamura, S., Somemura, H., Sasaki, N., Yamamoto, M., Tanaka, M., \& Tanaka, K. (2016). Effect of management training in organizational justice: A randomized controlled trial. Industrial Health, 54(3), 263-271. https://doi.org/10.2486/ indhealth.2015-0164

Nkosi, B. (2013). Minister is 'misleading public' on teacher absenteeism. Retrieved from https://mg.co.za/article/2013-03-10-minister-is-misleading-public-on-teacherabsenteeism

Northcutt, N., \& McCoy, D. (2004). Interactive qualitative analysis: A systems method for qualitative research. Thousand Oaks, CA: Sage.

Podsakoff, N.P., LePine, J.A., \& LePine, M.A. (2007). Differential challenge stressorhindrance stressor relationships with job attitudes, turnover intentions, turnover, and withdrawal behavior: A meta-analysis. Journal of Applied Psychology, 92(2) 438-454. https://doi.org/10.1037/0021-9010.92.2.438

Reddy, V., Prinsloo, C.H., Arends, F., Visser, M., Winnaar, L., Feza, N., ... Ngema, M. (2012). Highlights from TIMSS 2011: The South African perspective. Pretoria: Human Sciences Research Council.

Reddy, V., Visser, M., Winnaar, L., Arends, F., Juan, A., Prinsloo, C.H., \& Isdale, K. (2016). TIMSS 2015: Highlights of mathematics and science achievement of Grade 9 South African learners. Pretoria: Human Sciences Research Council.

Richardson, P.W., \& Watt, H.M.G. (2006). Who chooses teaching and why? Profiling characteristics and motivations across three Australian universities Asia-Pacific Journal of Teacher Education, 34(1), 27-56. https://doi.org/10.1080/ 13598660500480290

Rothmann, S. (2014). Employee engagement in a cultural context. In C. Truss, R. Delbridge, K. Alfes, A. Shantz \& E. Soane (Eds.), Employee engagement in theory and practice (pp. 163-179). New York, NY: Routledge.

Schaufeli, W.B., \& Bakker, A.B. (2004). Job demands, job resources, and their relationship with burnout and engagement: A multi-sample study. Journal of Organizational Behavior, 25(3), 293-315. https://doi.org/10.1002/job.248

Schaufeli, W.B., \& Salanova, M.S. (2011). Work engagement: On how to better catch a slippery concept. European Journal of Work and Organizational Psychology, 20(1), slippery concept. European Journal of Work and Organize
39-46. https://doi.org/10.1080/1359432X.2010.515981

Schaufeli, W.B., Salanova, M.S., González-Romá, V.A., \& Bakker, A.B. (2002). The measurement of engagement and burnout: A two sample confirmatory factor analytic approach. Journal of Happiness Studies, 3(1), 71-92. https://doi. org/10.1023/A:1015630930326

Schleicher, A. (2011). Lessons from the world on effective teaching and learning environments. Journal of Teacher Education, 62(2), 202-221. https://doi. org $/ 10.1177 / 0022487110386966$
Seligman, M.E.P., \& Csikszentmihalyi, M. (2000). Positive psychology: An introduction American Psychologist, 55(1), 5-14. https://doi.org/10.1037/0003-066X.55.1.5

Simbula, S. (2010). Daily fluctuations in teachers' well-being: A diary study using the Job Demands-Resources model. Anxiety, Stress, \& Coping, 23(5), 563-584. https://doi.org/10.1080/10615801003728273

Sisask, M., Värnik, P., Värnik, A., Apter, A., Balazs, J., Balint, M., ... Wasserman, D. (2014). Teacher satisfaction with school and psychological well-being affects their readiness to help children with mental health problems. Health Education Journal, 73(4), 382-393. https://doi.org/10.1177/0017896913485742

Spaull, N. (2013). South Africa's education crisis: The quality of education in South Africa 1994-2011. Johannesburg: Centre for Development and Enterprise.

Tabane, R.J. (2010). Integration and learners' feelings of belonging in a desegregated former House of Delegates school. Unpublished doctoral dissertation. University of Pretoria, Pretoria, South Africa.

Tims, M., Bakker, A.B., \& Derks, D. (2012). Development and validation of the Job Crafting Scale. Journal of Vocational Behavior, 80(1), 173-186. https://doi. org/10.1016/j.jvb.2011.05.009

Tims, M., Bakker, A.B., \& Derks, D. (2013). The impact of job crafting on job demands, job resources, and well-being. Journal of Occupational Health Psychology, 18(2), 230-240. https://doi.org/10.1037/a0032141

Trong, K.L. (2010). The relative risk-percentage equity index: Measuring equity in reading achievement across PIRLS 2006 countries. Hamburg: International Association for the Evaluation of Education.

Van Den Broeck, A., Vansteenkiste, M., De Witte, H., \& Lens, W. (2008). Explaining the relationships between job characteristics, burnout, and engagement: The role of basic psychological need satisfaction. Work \& Stress, 22(3), 277-294. https://doi. org $/ 10.1080 / 02678370802393672$

Vermooten, N. (2018). Variance in employee engagement among public school teachers in the Western Cape Province: An exploratory study. Unpublished doctoral dissertation. Stellenbosch University.

World Economic Forum (WEF). (2017). The Global Competitiveness Report 20172018. Geneva: World Economic Forum.

Wilkinson, K. (2015). Checked: $80 \%$ of South African schools indeed 'dysfunctional'. Retrieved from https://mg.co.za/article/2015-03-25-are-80-of-south-africanRetrieved from https:
schools-dysfunctional

Wollard, K.K., \& Shuck, B. (2011). Antecedents to employee engagement: A structured review of the literature. Advances in Developing Human Resources, 13(4), 429-446. https://doi.org/10.1177/1523422311431220

Xanthopoulou, D., Bakker, A.B., Demerouti, E., \& Schaufeli, W.B. (2007). The role of personal resources in the job demands-resources model. International Journal of Stress Management, 14(2), 121-141. https://doi.org/10.1037/10725245.14.2.121

Xanthopoulou, D., Bakker, A.B., \& Fischbach, A. (2013). Work engagement among employees facing emotional demands: The role of personal resources. Journa of Personnel Psychology, 12(2), 74-84. https://doi.org/10.1027/1866-5888/ a000085 